\title{
Post-fire recovery of Abies cephalonica forest communities: the case of Mt Parnitha National Park, Attica, Greece
}

\author{
Anastasia Christopoulou ${ }^{(1-2)}$, \\ Dimitrios Kazanis ${ }^{(1)}$, \\ Nikolaos M Fyllas ${ }^{(3)}$, \\ Margarita Arianoutsou ${ }^{(1)}$
}

\begin{abstract}
Mountain coniferous forests of Southern Europe seem to be increasingly affected by large fires. Endemic Greek fir (Abies cephalonica) forests were among the most affected ecosystems by the 2007 extreme wildfires in Greece. The aim of this study is to investigate the pattern of post-fire regeneration of fir forest plant communities of Mount Parnitha National Park, in Attica (Greece), after a large wildfire. A network of 8 severely burned sites across the mountain ridge was established in order to monitor natural regeneration of A. cephalonica as well as post-fire floristic composition and species richness. Field campaigns took place in two distinct time periods, one close to the fire event and one 8 to 10 years after. Generalized linear models were used to explore the effects of distance and microhabitat variables on the post-fire regeneration of the Greek fir. Distance from the unburned patches, slope and cover of woody species significantly affected $A$. cephalonica seedling establishment and hence its natural post-fire regeneration. Floristic composition and plant species richness of the recovering fir communities changed through time. During the initial phase, high species richness was recorded, mainly because of the high contribution of herbaceous species. During the second period, species richness was lower and similar to that recorded in the unburned fir communities. It is during this period when the first seedlings of the Greek fir managed to establish, although their density is rather low to ensure full recovery of the forest.
\end{abstract}

Keywords: Greek Fir, Mountain Forests, Post-fire Regeneration, Vegetation Dynamics, Secondary Succession terranean region (cool-Mediterranean) remains rather uncertain. Some tree species growing in these forests, like Pinus nigra (Black pine), are well adapted to low intensity surface fires (Tapias et al. 2004, Fulé et al. 2008). On the other hand, other species such as Abies spp. are easily killed by fire (Wirth 2005), although in cooler and wetter climatic conditions favourable for fir species in the Mediterranean basin, fire risk and occurrence are considered rather low (Mitsopoulos et al. 2015).

However, there are cases where decrease in cover of such forest types has been recorded as a consequence of few but exten-
(1) Department of Ecology and Systematics, Faculty of Biology, National and Kapodistrian University of Athens, Panepistimiopolis, 15784 Athens (Greece); (2) Nicolaus Copernicus University, Institute for the Study, Conservation and Restoration of Cultural Heritage, ul. Sienkiewicza 30/32, 87-100 Torun (Poland); (3) Biodiversity Conservation Laboratory, Department of Environment, University of the Aegean, 81100 Mytilene (Greece)

@ Anastasia Christopoulou (anchristo@biol.uoa.gr)

Received: Jan 29, 2018 - Accepted: Aug 29, 2018

Citation: Christopoulou A, Kazanis D, Fyllas NM, Arianoutsou M (2018). Post-fire recovery of Abies cephalonica forest communities: the case of Mt Parnitha National Park, Attica, Greece. iForest 11: 757-764. - doi: 10.3832/ifor2744-011 [online 2018-11-15]

Communicated by: Davide Ascoli sive fire events. For instance, extensive loss of Abies pinsapo forests has been reported by Esteban et al. (2010), because of a large fire occurred in 1570 in Spain. During the last decades there is a positive trend of larger fire events in high coniferous ecosystems of Greece. In the summer of 2007, the burned area of high-land coniferous forest exceeded $43 \%$ of the total area burned in Peloponnese (Koutsias et al. 2012). Among the most affected forest types in 2007 fires were the mountainous forests of the endemic Abies cephalonica Loudon (Arianoutsou et al. 2010).

A. cephalonica (Greek fir) is a tree species endemic to southern continental Greece and the islands of Cephalonia (Ionian Sea) and Euboia (Aegean Sea). A. cephalonica represents one of the most important forest species, forming extended forests in southern Greece (Korakis 2015). Its annual precipitation during the growing season and thus climate change might pose a risk for this endemic species (Fyllas et al. 2017). A. cephalonica, like the majority of Abies species (Ali et al. 2008), is not adapted to fires. The species has neither a thick bark, that could protect the cambium from lethal heat release as in the case of Black pine (Tapias et al. 2004), nor forms serotinous cones with a canopy seed bank, which could provide the necessary seeds for postgrowth seems to be related to incoming 
fire recovery similar to many Mediterranean pines (Arianoutsou et al. 2010).

Greek fir is an anemochorous species whose seeds disperse from nearby unburned patches (Arianoutsou et al. 2010, Raftoyannis \& Spanos 2015). Nevertheless, seed dispersal from unburned trees does not necessarily imply adequate seedling recruitment (Retana et al. 2012). Findings from previous studies suggest that $A$. Cephalonica post-fire regeneration is greatly influenced by the prevailing climatic conditions. According to Ganatsas et al. (2012) the regeneration rate of burned $A$. cephalonica in Mount Parnitha, three years after the fire event, tends to be zero despite the existence of unburned fir stands in close proximity. On the contrary, Raftoyannis \& Spanos (2015) reported adequate regeneration twelve years after fire, but in a much Greece.

The aims of the current study were: (1) to investigate the factors that affect post-fire seedling establishment of the endemic $A$. cephalonica; and (2) to explore the postfire dynamics and recovery of the associated plant community. The results of the study can be of particular importance for providing scientific knowledge on the effects of fire on European fir forest ecosystems. Furthermore, this study can be used as reference for post-fire management plans of Greek fir forests and ecosystems more humid environment in Central

that share similar ecological characteristics, especially since an increase in wildfire frequency in higher elevation is expected under climate change scenarios.

\section{Materials and methods}

\section{Study area}

Mt. Parnitha, the highest (1413 $\mathrm{m}$ a.s.I.) and most extensive mountain near the Athens metropolitan area, has been designated as a National Park since 1961. It is also included in the Natura 2000 network both as a Special Area of Conservation (SAC) under the European Union Habitats Directive (Directive 92/43/EEC) and as a Special Protection Area (SPA) under the Birds Directive (Directive 2009/147/EC), with the name "Oros Parnitha" and the code GR3000001. The core zone of the National Park comprises the highest peaks of Mt. Parnitha, an area of about 3800 ha, of which $90 \%$ was covered until 2007 by $A$. cephalonica forests. Greek fir extends from an elevation of circa $800 \mathrm{~m}$ a.s.l. up to the top of the mountain. At lower elevation, the buffer zone of the strictly protected area is mainly covered by Pinus halepensis forests, expanding down to the foothills of the mountain.

One of the largest fires in the history of the Park took place in June 2007 and burned a large part ( $2180 \mathrm{ha}$ ) of the strictly protected area and almost $50 \%$ of the $A$.

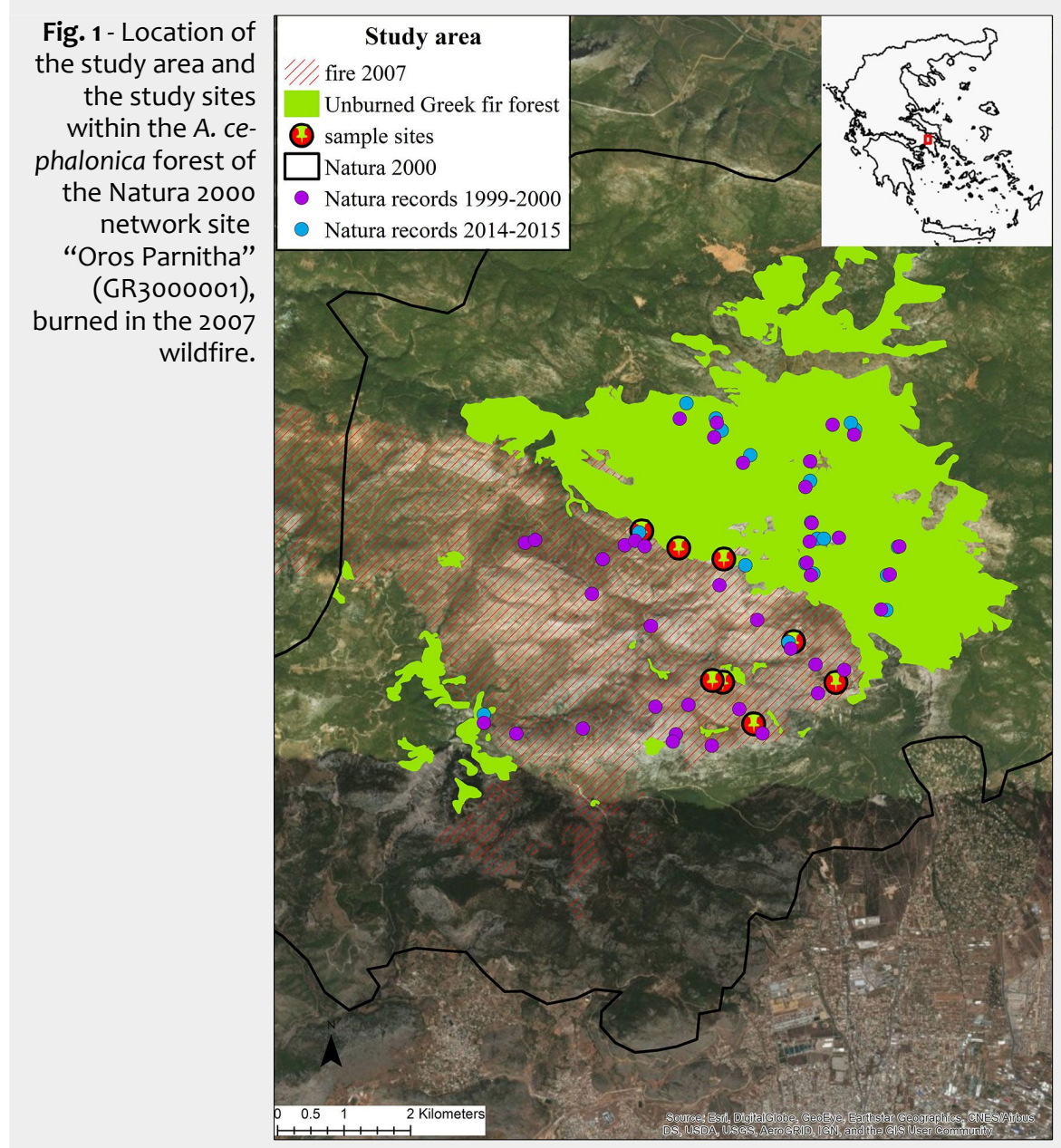

cephalonica forest. Fire did not burn the area in a homogeneous way, probably due to the topography of the mountain, the prevailing meteorological conditions and the tactics applied during fire suppression. As a result, several patches of various sizes have remained unburned inside the burned area.

\section{Study sites and field sampling}

In total, eight A. cephalonica burned stands were selected as sampling sites. For the purposes of this study we selected sites exclusively in areas where fire had completely consumed fir trees, thus fire severity was high. This selection would contribute to test: (i) the ability of burned plants to regenerate; and (ii) the role of adjacent unburned fir patches to the establishment of fir seedlings in the burned areas. Four of these sites were established close to the unburned edges of the forest, while the remaining four sites were established close to isolated unburned patches (Fig. 1). In each study site, three $120 \mathrm{~m}$ long permanent transects, starting from the outermost surviving tree, were established and a minimum distance of 50 meters was secured between them. Along each transect, a scheme of alternating square plots of $1 \mathrm{~m}^{2}$ was established, with the total number of plots per transect being 120. First records took place one year after the fire event and the same transects and plots (2880 plots in total) were revisited two, eight and ten years after the 2007 fire, during the spring and the early summer period.

Topographic variables such as the aspect and the elevation of the site were recorded. Stand characteristics such as the number of mature fir trees, maximum height and mean diameter at breast height (DBHm) of the unburned trees were also measured.

Assessment of post-fire fir regeneration was based on measurements that took place in each one of the alternating plots of $1 \mathrm{~m}^{2}$ along all transects in all sites. In order to achieve an indication of the available seed source, the number of dispersed $A$. cephalonica seeds was recorded during the first post-fire year (spring 2008) in each sampling plot. Because $A$. cephalonica seedlings were observed only after the $8^{\text {th }}$ post-fire year (2015), biotic and abiotic characteristics at the plot level were recorded at that year too. Measurements included the slope of the plot, the ground cover by rocks, snags and other woody remnants, as well as cover by herbaceous and woody species. All these records were expressed in a semiquantitative scale, with (I): ground cover <25\%; (II): ground cover between $25 \%$ and 75\%; and (III): ground cover $>75 \%$ (Tab. 1).

During the entire monitoring period (years 2008, 2009, 2015 and 2017) we additionally recorded the floristic composition and species richness in order to monitor vegetation dynamics of the recovering 
community. All plant taxa growing along each transect (and within the alternating plots of $1 \mathrm{~m}^{2}$ ) were recorded and classified according to their growth form. In order to avoid edge effect, vegetation measurements started at a distance longer than 50 $\mathrm{m}$ from the edge of the unburned stand. Taxa recorded during the first post-fire year (2008), were classified according to their regeneration mode as obligate resprouters (OR), obligate seeders (OS) and facultative seeders (FS). The latter category includes plants possessing both mechanisms for regenerating after fire (e.g., species that are able to resprout and to germinate after fire - Pausas \& Keeley 2014). The nomenclature of the plant taxa as well as their growth form followed Dimopoulos et al. (2013, 2016). Plant species composition of the regenerating communities was compared with the unburned $A$. cephalonica forest stands. This comparison was based on species lists derived from floristic data collected within the framework of the Natura 2000 Vegetation and Habitat Identification and Mapping project in 1999-2000 (Dafis et al. 2001) and in 2014-2015 (Dimopoulos et al., unpublished data). Additional floristic data for the mountain were derived from Aplada et al. (2007). Some of the records from the first Natura 2000 monitoring program (1999-2000) fall within the now burned fir forest (Fig. 1). As a final step, we assigned its taxon to ecological indicator values (EIV) following the approach by Ellenberg (1979) for specific climatic and edaphic eco-factors which can be important in burned communities, namely: light, temperature and moisture (Tab. S1 in Supplementary material). For this assignment we used EIV developed from Böhling et al. (2002) for Southern Aegean. Nonetheless, results should be treated with caution since the application of EIV is considered as reliable mostly within their region of their definition (Godefroid \& Dana 2007).

\section{Data analysis}

The Sørensen (Bray-Curtis) distance measure (McCune \& Grace 2002) was used in order to estimate compositional dissimilarities (Hollingsworth et al. 2013) among different post-fire years (burned) and unburned communities. The index used is a measure of dissimilarity, with 1 representing totally different communities. In order to plot differences among the different post-fire years of the study and the unburned fir forest in regard to floristic composition, we performed a hierarchical clustering using the "vegan" package in the $\mathrm{R}$ statistical software package ( $R$ Core Team 2017), following Oksanen et al. (2013). Three agglomerative clustering methods have been tested: single, complete and average linkage clustering. Cophenetic correlation was used to compare the dendrograms produced by each clustering method.

Due to their low presence, seedlings and saplings were aggregated together and

Tab. 1 - Summary of variables used in the mixed effect model. Regeneration was the response variable with the rest variables used as predictors, all measured at the plot level. For all cover variables a semiquantitative scale was used with (I): ground cover $<25 \%$ (absence); (II): ground cover $>25 \%$ and $<75 \%$ (intermediate presence): (III): ground cover $>75 \%$ (high presence). (a): units or scale provided in parenthesis.

\begin{tabular}{|c|c|c|}
\hline Variable & Description $^{(a)}$ & $\begin{array}{c}\text { Mean } \\
\text { (and/or range) }\end{array}$ \\
\hline Regeneration & A. cephalonica regeneration (seedlings or saplings $\mathrm{m}^{-2}$ ) & $0.02(0.00-2.00)$ \\
\hline Distance & Distance to unburned patches $(\mathrm{m})$ & $(0-120)$ \\
\hline Slope & Mean slope (I: low; II: intermediate; III: high) & low to high \\
\hline Herbs & Cover of herbs (I: low, II: intermediate, III: high) & low to high \\
\hline Woody & $\begin{array}{l}\text { Cover of woody species (I: low; II: intermediate; III: } \\
\text { high) }\end{array}$ & low to high \\
\hline $\begin{array}{l}\text { Branches and } \\
\text { Trunks }\end{array}$ & $\begin{array}{l}\text { Cover of fallen branches and trunks, stumps and snags } \\
\text { (I: low; II: intermediate; III: high) }\end{array}$ & low to high \\
\hline $\begin{array}{l}\text { Rock and } \\
\text { Stones }\end{array}$ & $\begin{array}{l}\text { Cover of stones and rocks (I: low; II: intermediate; III: } \\
\text { high) }\end{array}$ & low to high \\
\hline
\end{tabular}

treated collectively as regeneration density (individuals $\mathrm{m}^{-2}$ ) of the Greek fir. Seed density as well as regeneration density (number of seeds $\mathrm{m}^{-2}$ and number of seedlings + saplings $\mathrm{m}^{-2}$, respectively) were initially tested across four distance classes: $(A)$ distance $<10 \mathrm{~m}$; (B) $10 \mathrm{~m} \leq$ distance < $50 \mathrm{~m}$; (C) $50 \mathrm{~m} \leq$ distance < $100 \mathrm{~m}$; and (D) distance $\geq 100 \mathrm{~m}$ from the edge of the unburned patch. Kruskal-Wallis (KW) nonparametric tests and post-hoc multiple comparison tests were used to detect statistical significant difference of seed and regeneration density across the different distance classes, using the "agricolae" package (De Mendiburu 2017). In this analysis plot was used as the sample unit.

We additionally developed generalized general linear models (GLMs), with a Poisson error distribution, to explore the effects of distance and microhabitat variables on A. cephalonica post-fire regeneration density. Again, plot was used as the sample unit. We initially fit a full model using Distance, Slope, Woody Cover, Herb Cover, Branches and Trunks Cover, and Rock and Stone Cover (Tab. 1) as predictor variables. Before fitting the model we tested for correlation between all predictor variables. Some of these correlations were statistically significant but not very strong; the strongest one found between Slope and Herb Cover (Pearson's $\rho=-0.37$, $\mathrm{p}<0.001)$. We then dropped each explanatory variable, in turn, and applied an analysis of deviance test, to identify the most important predictors (Zuur et al. 2009). Overdispersion was tested using the "dispersiontest" function of the AER package. Finally, following a backward elimination procedure we fit a GLM with the predictor variables that had a statistically significant effect. Before fitting the GLM we tested the performance of a generalized linear mixed effect model (GLMM), with transects treated as random effects and the predictors of the GLM considered as fixed factors, using the "Ime4" package (Bates et al. 2015), and following the model selection procedure described in Zuur et al.
(2009). Those set of models did not yield a significantly better performance, with AIC dropping only by 4 units and thus we are not reporting their results here. Because of the many zeros included in our dataset (approximately $97 \%$ of the plot had no regeneration) we also fit a zero inflated model (ZIM) using the same predictor variables, a Poisson distribution and a log link function using the "pscl" package, in order to test whether the same predictor variables are identified by the GLM and the ZIM.

\section{Results}

\section{Post-fire communities}

A total of 160 plant taxa were recorded in the burned stands throughout the study period, while in the adjacent stands remaining unburned within the periphery of the 2007 fire event, 148 plant taxa were identified (Fig. 2, Tab. S1 in Supplementary material). Although total species richness was similar in burned and unburned forest communities, 60 out of 148 taxa (40.5\%), recorded in mature fir forest were absent from the burned study sites. Some of these species are very common representatives of $A$. cephalonica forests understory, including the perennial herbs Crepis fraasii, Luzula forsteri and Silene italica, the woody liana Lonicera sp. and others. On the other hand, 72 taxa found in the burned sites were absent from the unburned $A$. cephalonica stands. Most of them (85\%) are annual and perennial herbs, representing pioneer species mainly regenerated by seed germination. Meanwhile, some woody seeding species such as Cistus salvifolius and Thymelaea tartonraira found in the burned communities were absent in the unburned stands. More than half $(55 \%)$ of the taxa inhabiting the unburned $A$. cephalonica communities have regenerated successfully after fire. Twenty-three taxa recorded in the first post-fire year (2008) (34\% of the total) have resprouted, 44 taxa $(65 \%)$ regenerated through seed germination and one taxon (Convolvulus elegantissimus) regenerated by both modes. 
Fig. 2 - Number of plant taxa per post-fire year of study and total

number of taxa in

the burned and unburned fir forest.

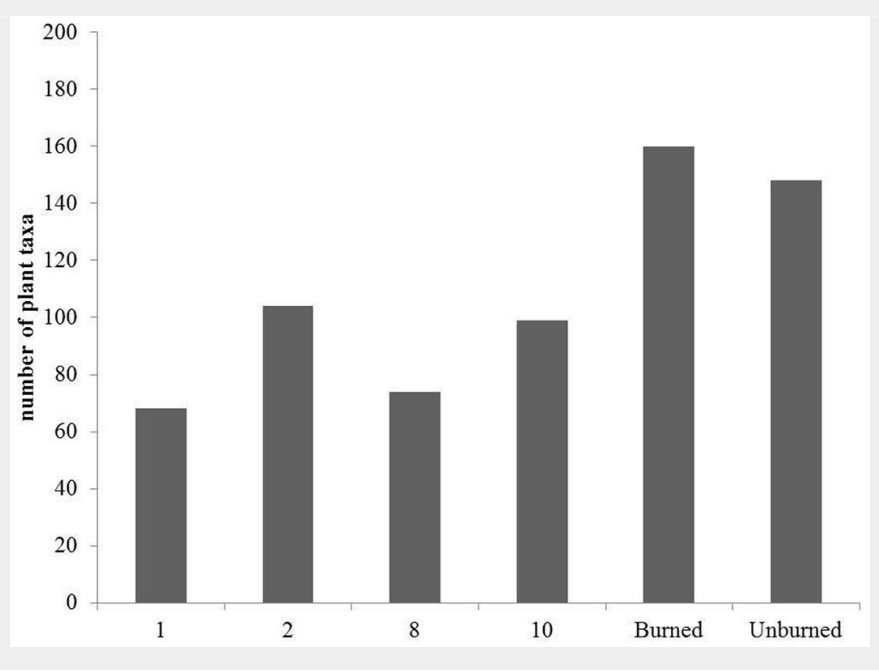

Tab. 2 - Sørensen's distance in terms of floristic composition among different post-fire years (burned) and unburned sites.

\begin{tabular}{lcccc}
\hline Site/Year & 2008 & 2009 & 2015 & 2017 \\
\hline 2009 & 0.267442 & - & - & - \\
2015 & 0.535211 & 0.52809 & - & - \\
2017 & 0.520958 & 0.399015 & 0.341041 & - \\
Unburned & 0.703704 & 0.611111 & 0.612613 & 0.465587 \\
\hline
\end{tabular}

Fig. 3 - Similarity analysis of floristic composition in burned and unburned fir forest stands. Results of average linkage agglomerative clustering (cophenetic correlation $=0.860$ )

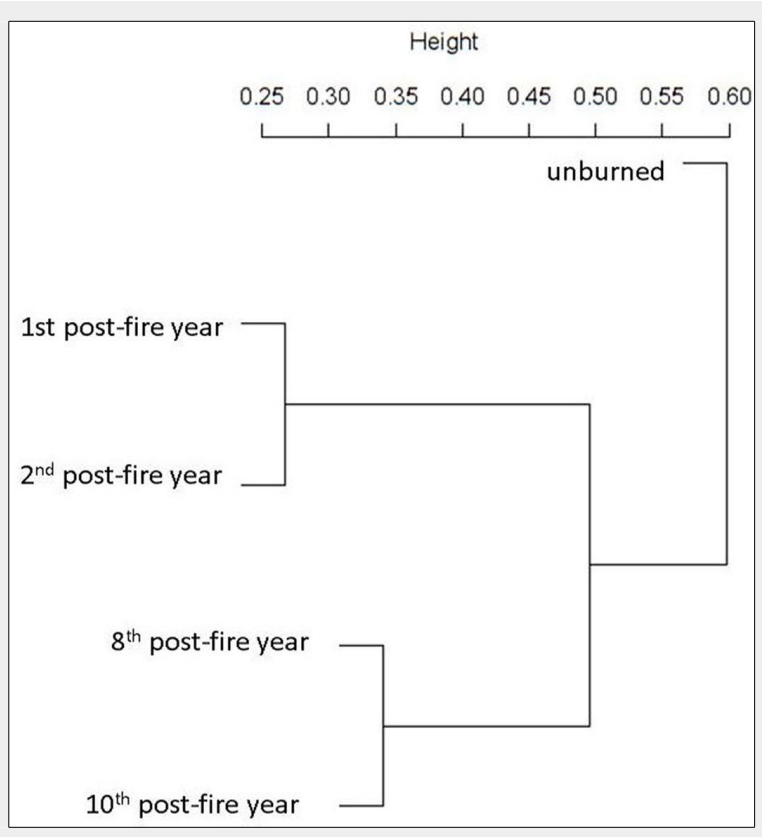

Tab. 3 - Summary of the analysis of deviance used to identify the optimal model of Abies cephalonica regeneration density. Deviance, Akaike's Information Criterion (AIC) and likelihood ratio test (LRT) of nested models were compared to the full model and tested with $\chi^{2}$ test. Significant $p$-values $(p<0.05)$ indicate that the respective predictor has a significant effect.

\begin{tabular}{lcccrc}
\hline Predictor & df & Deviance & AIC & \multicolumn{1}{c}{ LRT } & p \\
\hline Full Model & - & 240.19 & 333.26 & - & - \\
\hline Distance & 1 & 244.15 & 335.22 & 3.96 & 0.047 \\
\hline Slope & 2 & 265.36 & 354.43 & 25.17 & 0.000 \\
\hline Woody & 2 & 250.92 & 339.99 & 10.73 & 0.005 \\
\hline Branches and Trunks & 2 & 243.52 & 332.58 & 3.33 & 0.190 \\
\hline Rocks and Stones & 2 & 240.86 & 329.93 & 0.67 & 0.716 \\
\hline Herbs & 2 & 240.34 & 329.41 & 0.15 & 0.927 \\
\hline
\end{tabular}

As recovery process proceeded, species richness and floristic composition of the regenerating communities varied. Between the plant communities studied, those of the $1^{\text {st }}$ and the $2^{\text {nd }}$ post-fire year were more similar to each other (Sørensen distance $=$ 0.27 ), while the floristic composition of the $8^{\text {th }}$ post-fire year was more similar to the $10^{\text {th }}$ year after fire (Tab. 2, Fig. 3), suggesting two floristically distinct periods in the recovery process. This is also shown in the dendrogram, where the first two post-fire years were grouped, whereas the $8^{\text {th }}$ and $10^{\text {th }}$ post-fire years formed another distinct group (Fig. 3). According to Sørensen's distance and the cluster dendrogram, the lowest dissimilarity between unburned forest and burned forest communities is recorded for the $10^{\text {th }}$ year after fire (Tab. 2, Tab. 3). This implies that 10 years after fire the recovering fir community starts to resemble more to the unburned mature fir forest.

The highest species richness was recorded during the second post-fire year, with 104 plant taxa (Fig. 2), due to the higher number of annual and perennial herbaceous species, representing $88 \%$ of the total richness (Fig. 4). Among the herbaceous species the most common were annuals such as Arabidopsis thaliana, Cerastium brachypetalum and Trifolium arvense. Herbaceous species were highly represented in the recovering community during the first post-fire year, with Trifolium arvense and Vicia lathyroides being the most common ones. The contribution of woody species to the early recovering community is limited and mainly with short shrubs such as Cistus creticus. Tall shrubs such as Quercus coccifera and Rhamnus lycioides were also present, but their presence was much lower compared to the following years. During the early post-fire years no A. cephalonica seedlings were observed in burned sites. Similarly, no regeneration of Juniperus oxycedrus, the most abundant shrub of the unburned fir forest understory, was observed during the same period. The percentage of woody taxa, including both shrubs and tree species, increased from $12 \%$ of the total recorded number of plant taxa during the first postfire year (2008) to $26 \%$ during the $8^{\text {th }}$ year after fire (2015). Of particular importance is the presence of woody species which are absent from the unburned $A$. cephalonica stands, such as Quercus pubescens, Pinus halepensis and Pinus nigra. The first two species are native in the study area but are normally distributed at lower altitudes, whereas Black pine stands are the result of older plantations.

In terms of plant families' richness, the number of families in post-fire plant communities gradually increased following the fire event, from 22 families in the first postfire year to 32 families ten years after the fire. Regarding ecological indicator values, scores were assigned to 129 out of 220 taxa recorded both in burned and unburned fir stands, based on Böhling et al. (2002). Re- 

post-fire year of study and total number of taxa in the

burned and unburned fir forest. (AH): annual herb; (PH): perennial herb; (Ss): short shrub; (S): shrub; (Ts): tall shrub/tree; $(\mathrm{T})$ : tree; (L): liana; (Unk): not classified.
Fig. 4 - Number of plant taxa per growth form, per 100

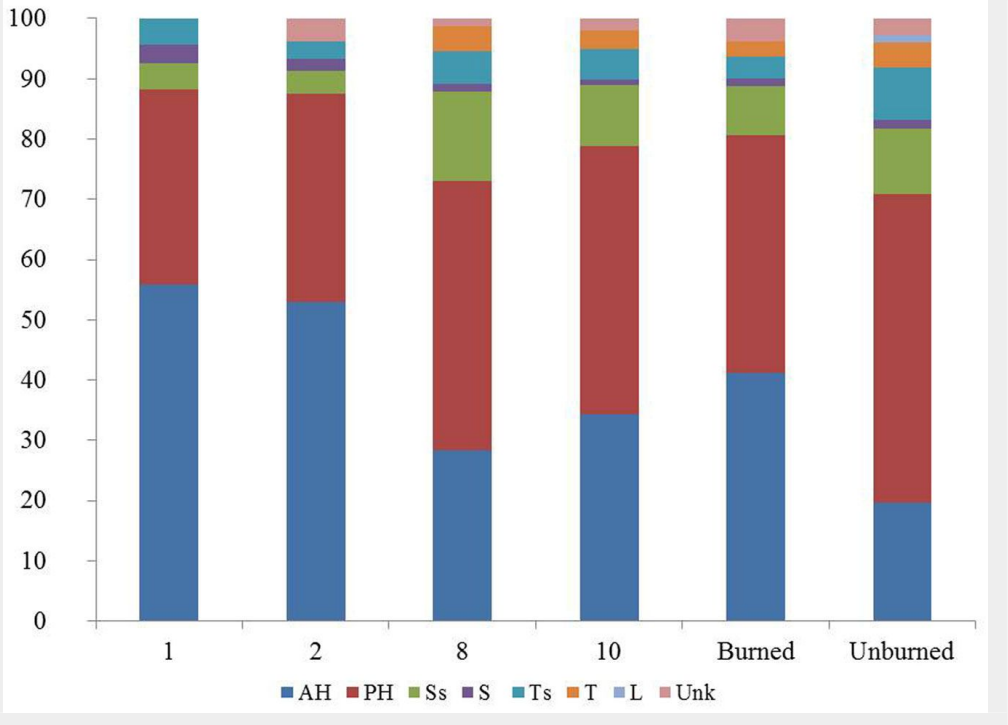

Fig. 5 - Mean A. cephalonica seed and regeneration density in four distance classes from the edges of the unburned patches and standard deviation. (A): distance $<10 \mathrm{~m}, \mathrm{n}=160 ;(\mathrm{B}): 10 \mathrm{~m} \leq$ distance $<50 \mathrm{~m}, \mathrm{n}=$ 610; (C): $50 \mathrm{~m} \leq$ distance $<100 \mathrm{~m}, \mathrm{n}=720$; and (D) distance $\geq 100, n=72$. Results of the KW non-parametric tests and post-hoc multiple comparison tests for seed and regeneration density are marked within the graph with small letters. Distance classes with different small letters are significantly different from each other $(p<$ $0.05)$.
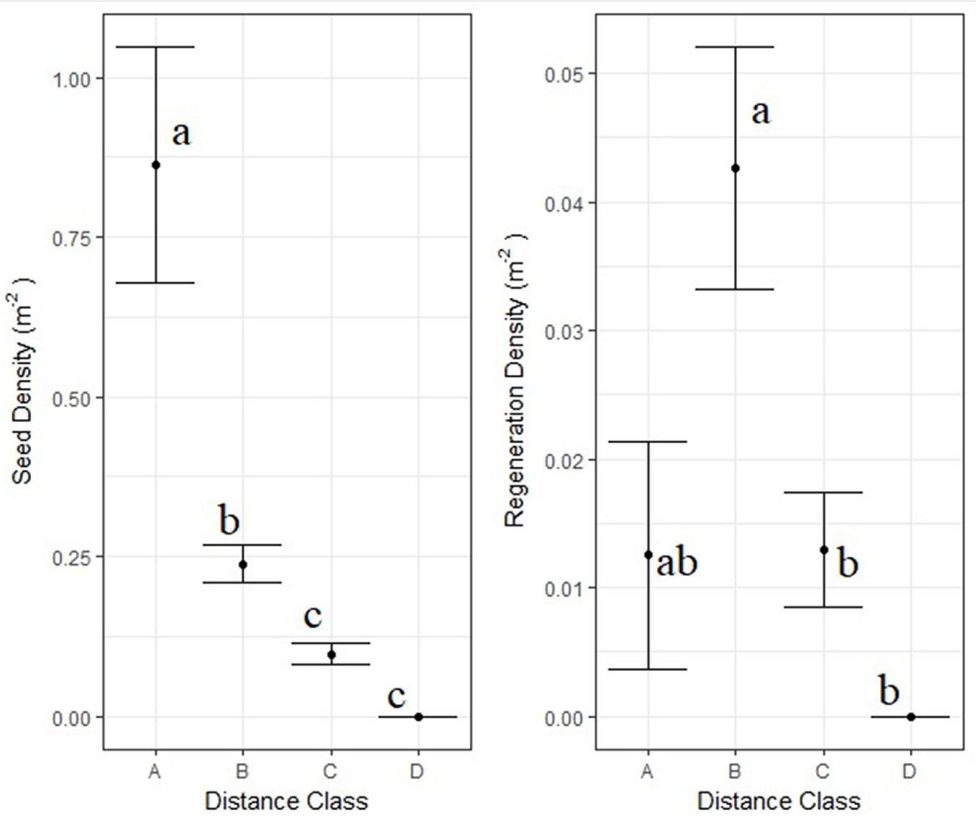

sults do not highlight any striking difference between burned and unburned plant communities concerning climatic factors, although they should be treated with caution since existing EIV for Greece do not cover the study area. Nevertheless, the higher percentage of light-demanding taxa in the recovering burned communities as compared to those in the unburned ones ( $49 \%$ vs. $35 \%$ ) is noteworthy.

\section{Abies cephalonica seed dispersal and natural regeneration}

During the first post-fire year 358 seeds ( $2200 \pm 9500$ seeds ha $^{-1}$ ) were recorded in the burned areas being dispersed from $A$. cephalonica trees that have remained unburned. These trees are located either in unburned patches within the periphery of burned area or at the edge of the fire periphery. Seventy nine percent (79\%) of the seeds were found within the first $50 \mathrm{~m}$ from the edge of the unburned patch.

No seedlings of $A$. cephalonica were re- corded in the burned area during the first ha-1). Seventy-four per cent (74\%) of the $A$. two post-fire years. Only 38 seedlings and cephalonica regeneration density (seedling saplings were recorded during the entire + saplings) was recorded within the first 50 study period of 10 years. The overall regen- $\mathrm{m}$ from the edge of the unburned patch. eration density in the burned areas re- Results of Kruskal-Wallis and the respective mained rather low, with a mean density of post-hoc test are presented in Fig. 5. Not a 0.02 individuals $\mathrm{m}^{-2}(200 \pm 1700$ individuals single seed or seedling was detected at dis-

Tab. 4 - Coefficients of the optimal model (GLM with a Poisson error distribution and log link function) predicting Abies cephalonica regeneration density as a function of distance and microenvironmental (cover) variables. P-values lower than 0.05 indicate a statistically significant effect of the predictor variable. A pseudo- $R^{2}=17.85 \%$ was estimated as the proportion of explained deviance.

\begin{tabular}{lccc}
\hline Predictor & Estimate & SE & p-value \\
\hline Intercept & -6.05 & 1.03 & 0.000 \\
\hline Distance & -0.01 & 0.01 & 0.021 \\
\hline Slope II & 3.20 & 1.02 & 0.002 \\
\hline Slope III & 1.75 & 1.24 & 0.160 \\
\hline Woody II & 0.87 & 0.35 & 0.014 \\
\hline Woody III & 2.87 & 0.78 & 0.000 \\
\hline
\end{tabular}


tances longer than 100 meters from the edge of the unburned patch.

The analysis of deviance of the GLM is summarised in Tab. 3. The optimal model included the distance from unburned stands, the slope and woody cover of the plot as important predictors. As expected, distance had a negative effect on regeneration density (Tab. 4). Higher densities were observed at moderate slope plots, with low and high slope plots showing no difference between them. In addition, higher regeneration densities were found at plots with higher woody cover. The optimal model showed no overdispersion $(Z=1.359$, $p=0.09)$ and it accounted for $17.85 \%$ of the deviance. Interestingly, the ZIM model identified the same predictor variables as the most important ones for predicting $A$. cephalonica regeneration density, enhancing our confidence in the GLM prediction.

\section{Discussion}

During the first post-fire years plant species richness was higher in the burned $A$. cephalonica communities compared to the unburned ones on Mount Parnitha, with higher contribution from light-demanding taxa. This finding is in accordance with studies in thermo-Mediterranean ecosystems (e.g., Pinus halepensis - Kazanis \& Arianoutsou 1996, Arianoutsou \& Neeman 2000, Ganatsas et al. 2004), but also in Mediterranean forests found at higher elevations (e.g., Pinus sylvestris - Herranz et al. 1996; or Pinus nigra - Ocak et al. 2007). The higher species richness was mainly attributed to the increased presence of annual and perennial herbs, especially during the early post-fire period. This is also reflected to families' richness, with Asteraceae, Fabaceae and Poaceae being the ones with the highest number of taxa, as is also the case in other Meso-Mediterranean ecosystems (Ocak et al. 2007). The higher number of species in Asteraceae and Poaceae families, especially during the second post-fire year, is due to the increased presence of anemochorous species, whose regeneration depends on long distance seed dispersal (Paula et al. 2009, Arianoutsou et al. 2010). During the early period herbaceous species dominated, whereas woody species, including shrubs such as Juniperus oxycedrus, were mainly found during the second post-fire period of the study. The highest floristic similarity with the unburned forest community was observed ten years after the fire event. This could illustrate a similar pattern with the one documented for the post-fire recovery of $P$. halepensis communities, where species richness during the first post-fire years is higher than in unburned mature forests, followed by a gradual but continuous decrease from the third post-fire year onwards, until a constant value typical to mature unburned forests is reached (Arianoutsou \& Neeman 2000).

During the first two post-fire years no $A$. cephalonica seedling was found, as re- ported also by Ganatsas et al. (2012) for the same area. The first seedlings were recorded only 8 years after fire. A. cephalonica is not adapted to fire and its natural post-fire recovery is limited and strongly dependent on seed dispersal from neighboring unburned individuals or patches (Arianoutsou et al. 2010, Raftoyannis \& Spanos 2015). As supported also by other studies focusing on obligate seeders (Calvo et al. 2016), the availability of seeds was not necessary translated into successful postfire regeneration. A. cephalonica recruitment ten years after fire remains rather poor (200 individuals ha-1), in comparison to the available seed numbers recorded during the first post-fire year (2200 seeds $\left.\mathrm{ha}^{-1}\right)$. There are several factors that may explain the delayed appearance of A. cephalonica seedlings, including the peculiarities of the its reproductive biology, seed predation and lack of suitable microhabitats for seedling establishment. A. cephalonica possess a masting behavior (Politi et al. 2009, Politi et al. 2011) expressed in an inter-annual variability on cone and seed production (Politi et al. 2011). According to Politi et al. (2011), there is a high inter-annual variability in the number of adult trees bearing cones, as well as in cones produced per tree and respective viable seed production. This reproductive pattern has a periodicity of 2-4 years and has also been found for the $A$. cephalonica population on Mount Parnitha (Ganatsas et al. 2012). Apart from differences in the annual cone and seed production, seed germination percentage is also varying from year to year and is low, even under laboratory conditions (Politi et al. 2011, Ganatsas et al. 2012). Seed predation is another key factor in species postfire regeneration, as it can notably limit seedlings establishment (Ordóñez \& Retana 2004).

Delayed appearance of $A$. cephalonica seedlings could also be attributed to the lack of suitable microhabitats for their establishment and competition with other species. According to Politi et al. (2011), A. cephalonica seed germination can equally occur in any light regime found in the forest, whereas seedling establishment and survival in time is better accomplished in the protective shade offered by elder plants. The difficulty in successfully regenerating after large wildfire events has been reported for other high elevation coniferous species (Ordóñez et al. 2005, Christopoulou et al. 2014) emphasizing the negative impact of drought as well as the importance of unburned mature individuals for the successful recruitment of such species. In the study area, the direct exposure of $A$. cephalonica seedlings during the first postfire years to summer heat may be detrimental for their survival. Nevertheless, the gradual appearance of woody species, as supported from the GLM results, seems to favor seedlings survival, probably acting as nurse plants that provide more favourable micro-habitats (potential protection against high radiation, extreme temperatures etc.). This is also documented for other coniferous species (Tíscar \& Linares 2011), including some Abies species too (Sánchez-Velásquez et al. 2011). Furthermore, as observed for Mediterranean conifers (e.g., Pinus halepensis - García-Jiménez et al. 2017) recruitment is favored on moderate slopes, due to seeds accumulation and increased water retention capacity.

Ten years after fire, Greek fir's regeneration in Mt Parnitha National Park remains rather poor. Raftoyannis \& Spanos (2015) reported higher fir density of 1436 seedlings ha ${ }^{-1}, 12$ years after fire in a cooler mountain region of Central Greece. Nonetheless, we found the same spatial pattern of decreasing seed and regeneration density with distance from the edge of the unburned patch, as expected for wind-dispersed species (Nathan \& Casagrandi 2004, Nathan \& Neeman 2004, Raftoyannis \& Spanos 2015). According to Cremer et al. (2012), the median distance of seed dispersal of Abies alba, another fir species which like $A$. cephalonica produces winged seeds dispersed by wind, was $31 \mathrm{~m}$. In our study, more than $70 \%$ of the dispersed seeds and young firs were found within a distance shorter than $50 \mathrm{~m}$ from the parent trees. This is similar to the results of the dispersal curve of most wind-dispersed tree species, which show a peak at, or very close to, the source, followed by a rapid decline, and a long tail (Nathan \& Casagrandi 2004, Nathan \& Neeman 2004). The presence of log and branch barriers constructed in order to minimize erosion risk was not found to be important in post-fire recovery of the dominant species, as suggested for thermoMediterranean pine forests (Raftoyannis \& Spanos 2005). Canopy cover of unburned trees could not be an explanatory variable, as the seeds are dispersed outside the area of the canopy, in the open burned space.

In contrast to Raftoyannis \& Spanos (2015) who reported an adequate post-fire fir regeneration for a successful recovery of fir stands in a cooler site, Ganatsas et al. (2012) concluded that the burned fir stands in the much drier conditions of Mount Parnitha are more likely to become shrublands and grasslands in the next decades, if fir natural regeneration continues at this low rate.

\section{Conclusions}

Ten years after the 2007 wildfire on Mount Parnitha National Park recovery of the plant community is satisfactory. Woody species that were absent during the initial post-fire period started to gradually appearing in burned communities 8 years after and their presence seems to facilitate the establishment of A. cephalonica seedlings and saplings. However, it should be noted that the recruitment density of $A$. cephalonica is rather low and slow to ensure full recovery of the forest. The low levels of $A$. cephalonica regeneration can be attributed both to the ecological character- 
istics of the species, but also to the prevailing drought after fire, as suggested also for other Abies species (Harvey et al. 2016). The presence of more competitive and drought tolerant tree species like $P$. halepensis normally found at lower elevations could be the beginning of a shift to drier forest ecosystems. Local managers and foresters should carefully consider which species they will use in restoration practices, since the expected further increase in drought events can facilitate their expansion and dominance against local species, especially after disturbances such as fire.

\section{Acknowledgments}

Comments from two anonymous reviewers greatly improved this study. The authors would like to thank the Management Authority of Mt Parnitha National Park. Effie Ganou, Tomas Tountas, Marula Tsagkari, Eleni Peppa and Elena Gianouli are acknowledged for their contribution to field work. Additional thanks are due to Dr. loannis Bazos for his support in plant taxa identification. We would also like to thank Prof. Beatriz Perez Ramos for valuable discussions and comments on the analysis of the data. Georgios-Pavlos Farangitakis, PhD student at Durham University (UK), has assisted in the linguistic improvement of the text.

\section{References}

Ali AA, Asselin H, Larouche AC, Bergeron Y, Carcaillet C, Richard PJH (2008). Changes in fire regime explain the Holocene rise and fall of Abies balsamea in the coniferous forests of western Québec, Canada. The Holocene 18 (5): 693-703. - doi: 10.1177/0959683608091780

Aplada E, Georgiadis Th Tiniakou A, Theocharopoulos $M$ (2007). Phytogeography and ecological evaluation of the flora and vegetation of Mt Parnitha (Attica, Greece). Edinburgh Journal of Botany 64 (2): 185-207. - doi: 10.1017/Sog604 2860700087X

Arianoutsou M, Neeman G (2000). Post-fire regeneration of natural Pinus halepensis forests in the East Mediterranean Basin. In: “Ecology, Biogeography and Management of Pinus halepensis and P. brutia Forest Ecosystems in the Mediterranean Basin" (Ne'eman G, Trabaud L eds). Backhuys, Leiden, The Netherlands, pp. 269-290.

Arianoutsou M, Christopoulou A, Kazanis D, Tountas Th Ganou E, Bazos I, Kokkoris I (2010). Effects of fire on high altitude coniferous forests of Greece. In: Proceedings of the "VI International Conference on Forest Fire Research" (Viegas DX eds). Coimbra, Portugal, pp. 12. [online] URL: http://www.researchgate.net/publica tion/274193148

Bates D, Maechler M, Bolker B, Walker S (2015). Fitting linear mixed-effects models using Ime4. Journal of Statistical Software 67 (1): 1-48. - doi: 10.18637/jss.v067.io1

Böhling N, Greuter W, Raus T (2002). Indicator values for vascular plants in the Southern Aegean (Greece). Braun-Blanquetia 32: 1-109. Bond WJ, Woodward Fl, Midgley GF (2005). The global distribution of ecosystems in a world without fire. New Phytologist 165: 525-538. doi: 10.1111/j.1469-8137.2004.01252.x

Calvo L, Hernández V, Valbuena L, Taboada A (2016). Provenance and seed mass determine seed tolerance to high temperatures associated to forest fires in Pinus pinaster. Annals of Forest Science 73: 381-391. - doi: 10.1007/s13595015-0527-0

Christopoulou A, Fyllas N, Andriopoulos P, Koutsias N, Dimitrakopoulos $\mathrm{P}$, Arianoutsou $\mathrm{M}$ (2014). Post-fire regeneration patterns of Pinus nigra in a recently burned area in Mount Taygetos, Southern Greece: the role of unburned forest patches. Forest Ecology and Management 327: 148-156. - doi: 10.1016/j.foreco.2014.05.006 Cremer E, Ziegenhagen B, Schulerowitz K, Mengel C, Donges K, Bialozyt R, Hussendorfer E, Liepelt S (2012). Local seed dispersal in European silver fir (Abies alba Mill.): lessons learned from a seed trap experiment. Trees 26: 987996. - doi: 10.1007/s00468-012-0676-9

Dafis S, Papastergiadou E, Lazaridou E, Tsiafouli $M$ (2001). Technical manual of mapping of Greek habitat types. Greek Biotope - Wetland Centre (EKBY), Thessaloniki, Greece, pp. 393.

Dimopoulos P, Raus T, Bergmeier E, Constantinidis T, latrou G, Kokkini S, Strid A, Taznoudakis D (2013). Vascular plants of Greece: an annotated checklist. Botanic Garden and Botanical Museum Berlin-Dahlem and Hellenic Botanical Society [Englera 31], Berlin, Germany and Athens, Greece, pp. 372.

Dimopoulos P, Raus T, Bergmeier E, Constantinidis T, latrou G, Kokkini S, Strid A, Taznoudakis D (2016). Vascular plants of Greece: an annotated checklist. Willdenowia 46 (3): 301-347. - doi: 10.3372/wi.46.46303

Ellenberg H (1979). Zeigerwerte von Gefässpflanzen Mitteleuropas [Indicator values of vascular plants of Central Europe]. Scripta Geobotanica 9: 1-122. [in German]

Esteban LG, De Palacios P, Rodriguez-Losada Aguado L (2010). Abies pinsapo forests in Spain and Morocco: threats and conservation. Oryx 44 (2): 276-284. - doi: 10.1017/S0030605310000 190

De Mendiburu F (2017). Agricolae: statistical procedures for agricultural research. $\mathrm{R}$ package version 1.2-8. [online] URL: http://CRAN.R-proj ect.org/package=agricolae

Fulé PZ, Ribas M, Gutiérrez E, Vallejo R, Kaye $M W$ (2008). Forest structure and fire history in an old Pinus nigra forest eastern Spain. Forest Ecology and Management 255: 1234-1242. - doi: 10.1016/j.foreco.2007.10.046

Fyllas NM, Christopoulou A, Galanidis A, Michelaki CZ, Dimitrakopoulos PG, Fulé PZ, Arianoutsou M (2017). Tree growth-climate relationships in a forest-plot network on Mediterranean mountains. Science of the Total Environment 598: 393-403. - doi: 10.1016/j.scitotenv.2017.04. 145

Ganatsas P, Zagas T, Tsakaldimi M, Tsitsoni T (2004). Post-fire regeneration dynamics in a Mediterranean type ecosystem in Sithonia, northern Greece: ten years after the fire. In: Proceedings of the " $10^{\text {th }}$ MEDECOS Conference" (Arianoutsou M, Papanastasis V eds). Rhodes (Greece) Apr 25 - May 1 2004. Millpress, Rotterdam, Netherlands, pp. 1-9. [online] URL: http://users.auth.gr/users/5/9/050495/public_ht $\mathrm{ml} /$ files/eng/20.pdf

Ganatsas P, Daskalakou E, Paitaridou D (2012). First results on early post-fire succession in an Abies cephalonica forest (Parnitha National Park, Greece). iForest 5: 6-13. - doi: 10.3832/ifor 0600-008

García-Jiménez R, Palmero-Iniesta M, Espelta JM (2017). Contrasting effects of fire severity on the regeneration of Pinus halepensis Mill. and resprouter species in recently thinned thickets. Forests 8: 55. - doi: 10.3390/f8030055

Godefroid S, Dana ED (2007). Can Ellenberg's indicator values for Mediterranean plants be used outside their region of definition? Journal of Biogeography 34: 62-68. - doi: 10.1111/j.13652699.2006.01582.x

Harvey BJ, Donato DC, Turner MG (2016). High and dry: post-fire tree seedling establishment in subalpine forests decreases with post-fire drought and large stand-replacing burn patches. Global Ecology and Biogeography 25: 655-669. - doi: 10.1111/geb.12443

Herranz JM, Martinez-Sanchez JJ, De Las Heras $J$, Ferrandis P (1996). Stages of plant succession in Fagus sylvatica L. and Pinus sylvestris L. forest of Tejera Negra National Park (Central Spain), three years after fire. Israel Journal of Plant Science 44: 347-358. - doi: 10.1080/079299 78.1996 .10676656

Hollingsworth TN, Johnstone JF, Bernhardt EL, Chapin FSIII (2013). Fire severity filters regeneration traits to shape community assembly in Alaska's boreal forest. PLoS ONE 8(2): e56033. doi: 10.1371/journal.pone.0056033

Kazanis D, Arianoutsou M (1996). Vegetation composition in a post-fire successional gradient of Pinus halepensis forests in Attica, Greece. International Journal of Wildland Fire 6 (2): 83-91. - doi: 10.1071/WF9960083

Korakis G (2015). Forest botany. SEAB, NTUA, Athens, Greece, pp. 620.

Koutsias N, Arianoutsou M, Kallimanis AS, Mallinis G, Halley JM, Dimopoulos P (2012). Where did the fires burn in Peloponnisos, Greece the summer of 2007? Evidence for a synergy of fuel and weather. Agricultural and Forest Meteorology 156: 41-53. - doi: 10.1016/j.agrformet.2011.12. 006

McCune B, Grace JB (2002). Analysis of ecological communities. MjM Software, Gleneden Beach, OR, USA, pp. 304.

Mitsopoulos I, Raftoyannis Y, Bakaloudis D (2015). Climate change, wildfires and fir forests in Greece: perceptions of forest managers. South-East European Forestry 6 (2): 143-157. doi: 10.15177/seefor.15-12

Nathan R, Casagrandi R (2004). A simple mechanistic model of seed dispersal, predation and plant establishment: Janzen-Connell and beyond. Journal of Ecology 92: 733-746. - doi: 10.1111/j.0022-0477.2004.00914.x

Nathan R, Neeman G (2004). Spatiotemporal dynamics of recruitment in Aleppo pine (Pinus halepensis Miller). Plant Ecology 171: 123-137. doi: 10.1023/B:VEGE.0000029379.32705.of Ocak A, Kurt L, Oz M, Tug N (2007). Floristic al and ecological studies on burned black pine ( $\mathrm{Pi}$ nus nigra Arn. subsp. pallasiana (Lamb) Holboe) forest area at Central Anatolia. Asian Journal of Plant Sciences 6: 892-905. - doi: 10.3923/ajps.20 
07.892 .905

Oksanen J, Blanchet FG, Kindt R, Legendre P, Minchin PR, Hara RB, Simpson GL, Solymos P, Stevens MHH, Wagner H (2013). vegan: Community Ecology Package. $\mathrm{R}$ package version 2.0-10. [online] URL: http://CRAN.R-project.org/ package =vegan

Ordóñez JL, Retana J (2004). Early reduction of post-fire recruitment of Pinus nigra by post-dispersal seed predation in different time-sincefire habitats. Ecography 27: 449-458. - doi: 10.1111/j.0906-7590.2004.03886.x

Ordóñez JL, Retana J, Espelta JM (2005). Effects of tree size, crown damage, and tree location on post-fire survival and cone production of $\mathrm{Pi}$ nus nigra trees. Forest Ecology and Management 206: 109-117. - doi: 10.1016/j.foreco.2004. 10.067

Paula S, Arianoutsou M, Kazanis D, Tavşanoğlu Ç, Lloret F, Buhk C, Ojeda F, Luna B, Moreno JM, Rodrigo A, Espelta JM, Palacio S, FernándezSantos B, Fernandes PM, Pausas JG (2009). Fire-related traits for plant species of the Mediterranean Basin. Ecology 90: 1420. - doi: 10.1890/08-1309.1

Pausas JG, Keeley JE (2014). Evolutionary ecology of resprouting and seeding in fire-prone ecosystems. New Phytologist 204: 55-65. - doi: 10.1111/nph.12921

Politi PI, Arianoutsou M, Stamou GP (2009). Patterns of Abies cephalonica seedling recruitment in Mount Aenos National Park, Cephalonia, Greece. Forest Ecology and Management 258:
1120-1136. - doi: 10.1016/j.foreco.2009.05.038

Politi PI, Georghiou K, Arianoutsou M (2011). Reproductive biology of Abies cephalonica Loudon in Mount Aenos National Park, Cephalonia, Greece. Trees 25: 655-668. - doi: 10.1007/soo46 8-011-0542-1

Raftoyannis Y, Spanos I (2005). Evaluation of log and branch barriers as post-fire rehabilitation treatments in a Mediterranean pine forest in Greece. International Journal of Wildland Fire 14: 183-188. - doi: 10.1071/WF04031

Raftoyannis Y, Spanos I (2015). Regeneration of Abies cephalonica Loudon after a large fire in Central Greece. South-Eastern European Forestry 6 (1): 5-14. [online] URL: http://hrcak. srce.hr/index.php?show=clanak\&id_clanak_jez $\mathrm{ik}=205182$ \&lang=en

R Core Team (2017). R: a language and environment for statistical computing. R Foundation for Statistical Computing, Vienna, Austria. [online] URL: http://www.r-project.org/

Retana J, Arnan X, Arianoutsou M, Barbati A, Kazanis D, Rodrigo A (2012). Post-fire management of non-serotinous pine forests. In: "PostFire Management and Restoration of Southern European Forests" (Moreira F, Arianoutsou M, Corona P, De las Heras J eds). Springer, Series Managing Forest Ecosystems vol. 24, Dordrecht, Heidleberg, London, New York, pp. 151170. - doi: 10.1007/978-94-007-2208-8_7

Sánchez-Velásquez L, Domínguez-Hernández D, Pineda-López M, Lara-González R (2011). Does Baccharis conferta shrub act as a nurse plant to the Abies religiosa seedling? The Open Forest Science Journal 4: 67-70. - doi: 10.2174/187439 8601104010067

Tapias R, Climent J, Pardos JA, Gil L (2004). Life histories of Mediterranean pines. Plant Ecology 171: 53-68. - doi: 10.1023/B:VEGE.0000029383.72 609.fo

Tíscar PA, Linares JC (2011). Structure and regeneration patterns of Pinus nigra subsp. salzmannii natural forests: a basic knowledge for adaptive management in a changing climate. Forests 2: 1013-1030. - doi: 10.3390/f2041013

Wirth C (2005). Fire regime and tree diversity in boreal forests: implications for the carbon cycle. In: "Forest diversity and function" (Scherer-Lorenzen M, Körner C, Schulze ED eds). Ecological Studies, vol. 176, Springer, Berlin, Germany, pp. 309-344. - doi: 10.1007/3-540-265996_15

Zuur AF, Leno EN, Walker N, Saveliev AA, Smith GM (2009). Mixed effects models and extensions in ecology with R. Springer, New York, NY, USA, pp. 574.

\section{Supplementary Material}

Tab. S1 - List of plant taxa recorded in burned and unburned stands, their growth form and regeneration mechanism for the taxa recorded during the first post-fire year.

Link: Christopoulou_2744@supploo1.pdf 